ISSN 1678-3921

Journal homepage: www.embrapa.br/pab

For manuscript submission and journal contents, access: www.scielo.br/pab

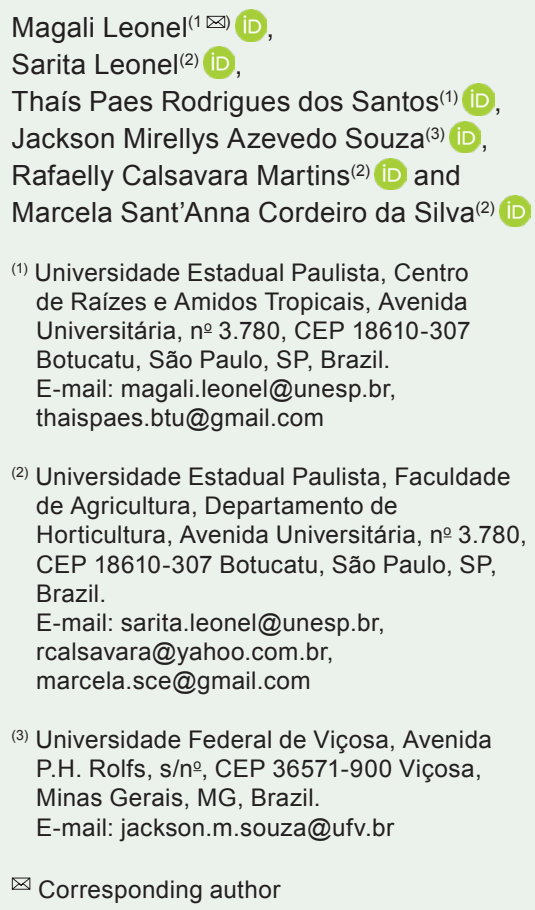

\section{Agronomic yield and starch properties of banana cultivars}

\begin{abstract}
The objective of this work was to evaluate the banana cultivars for their agronomic yield and starch characteristics. The experiment was carried out in a randomized complete block design, with a factorial arrangement of two cultivars ('BRS Conquista' and 'BRS Platina') and two crop cycles, with three plants per treatment, and five replicates. Fruit yield and starch quality were evaluated. 'BRS Conquista' showed smaller fruit; however, it had a greater marketable bunch weight and yield than 'BRS Platina'. Starches differed for the main physicochemical characteristics, except for X-ray diffraction pattern (B type) and phosphorus content $(0.0058-0.0060 \%)$. 'BRS Platina' stood out for its higher content of resistant starch $(74.55 \%)$ that differed from the starch isolated from 'BRS Conquista'. However, the starch of 'BRS Conquista' showed the following characteristics: larger granules (34.74 $\mu \mathrm{m})$, with greater crystallinity (33.64\%); less swelling power and solubility (26.77 $\mathrm{g} \mathrm{g}^{-1}$ and $19.21 \%$, respectively); and greater breakdown, setback and final viscosity $(67.06,182.42$, and $341.39 \mathrm{RVU}$, respectively). 'BRS Conquista' shows favorable production characteristics for processing to obtain starch. The higher resistant starch content of 'BRS Platina' may commercially justify its lower agronomic yield. Starches of the two cultivars show desirable characteristics for different industrial applications.
\end{abstract}

Index terms: Musa, BRS Conquista, BRS Platina, physicochemical characteristics.

\section{Rendimento agronômico e propriedades de amido de cultivares de banana}

Resumo - O objetivo deste trabalho foi avaliar cultivares de bananeira quanto aos seus rendimentos agronômicos e características de amido. $\mathrm{O}$ experimento foi realizado em blocos ao acaso, com arranjo fatorial de duas cultivares ('BRS Conquista' e 'BRS Platina') e dois ciclos da cultura, com três plantas por tratamento e cinco repetições. Avaliaram-se a produção e a qualidade do amido dos frutos. 'BRS Conquista' apresentou frutos menores; no entanto, mostrou maior massa comercial e produtividade do cacho do que 'BRS Platina'. Os amidos diferiram quanto às principais características físico-químicas, exceto quanto ao padrão de difração de raios X (tipo B) e teor de fósforo $(0,0058-0,0060 \%)$. 'BRS Platina' destacou-se por seu maior teor de amido resistente $(74,55 \%)$ que diferiu do amido isolado de 'BRS Conquista'. No entanto, o amido de 'BRS Conquista' apresentou as seguintes características: grânulos maiores $(34,74 \mu \mathrm{m})$, com maior cristalinidade (33,64\%); menor poder de inchamento e solubilidade $\left(26,77 \mathrm{~g} \mathrm{~g}^{-1}\right.$ e $19,21 \%$, respectivamente); e maiores quebra de viscosidade, tendência à retrogradação e viscosidade final $(67,06,182,42$ e $341,39 \mathrm{RVU}$, respectivamente). 'BRS Conquista' mostra características de produção favoráveis ao processamento para extração de amido. O maior teor de amido resistente de 'BRS Platina' pode justificar comercialmente sua menor produção agronômica. Os amidos das duas cultivares apresentam características desejáveis para aplicações industriais diversas.

Termos para indexação: Musa, BRS Conquista, BRS Platina, características físico-químicas. 


\section{Introduction}

Starch is an important ingredient in many food products. Its main commercial sources are corn, potatoes, rice, cassava, and wheat. However, there is currently a growing interest in the characterization of starches from unconventional sources, to meet functionality demands without the need for modification. In addition, there is interest in starchy foods with a low glycemic index, which increases the market potential for banana starch (Zhu, 2020; Tagliapietra et al., 2021).

The commercially exploited banana cultivars in Brazil are Prata, Grand Naine, Williams, and Nanicão. All of them have at least one undesirable characteristic at harvest, such as plant height, yield, and harvest time, intolerance to pests and diseases, and low resistance to drought or cold (Nomura et al., 2013).

The banana breeding program of Embrapa ("Programa de Melhoramento Genético da Bananeira") develops cultivars which show a great potential for introduction into the cultivation system because of their agronomic performance, resistance to pests and diseases, and potential for industrial raw material (Pereira \& Gasparoto, 2008). BRS Conquista cultivar (triploid AAB - subgroup Conquista) was obtained from a natural mutation in a plant population of the cultivar Thap Maeo in the experimental field of Embrapa Amazônia Ocidental, in the municipality of Manaus, in the state of Amazonas, Brazil. This cultivar is resistant to Panama disease (Fusarium oxysporum), yellow sigatoka leaf spot disease (Mycosphaerella musicola), and black sigatoka fungus (Mycosphaerella fijiensis, Morelet). The cultivar has high productivity and good pulp and peel yield (Pereira \& Gasparotto, 2008). BRS Platina cultivar is a tetraploid hybrid (AAAB - Prata/Pome type) from the crossing of 'Prataanã' (AAB) with the diploid M53 (AA), developed by Embrapa Mandioca e Fruticultura. This cultivar is resistant to Panama disease (Fusarium oxysporum) and yellow sigatoka leaf spot disease (Mycosphaerella musicola). The main disadvantage of BRS Platina cultivar is its susceptibility to falling off, which reduces the commercial value for the fresh market; however, this is not very important for industrial processing (Castricini et al., 2012; Nogueira et al., 2018).

Starch can be used in food industries where this polymer is widely used as a thickener, stabilizer, adhesive, colloidal agent, functional ingredient, as well as, to increase shelf life, decrease oil absorption, among others (Zhang \& Hamarker, 2012). The characteristics and structural properties of banana starch are affected not only by genotypes, but also by environmental factors (Utrilla-Coello et al., 2014; Mesquita et al., 2018).

The driving forces to explore unconventional starches, such as that of banana genotypes, are waste and by-product recovery, local availability, technological feasibility, cultural significance, and specialty food production (Zhu, 2020). Banana starch shows different physical and chemical properties from commercial starches, which increases the market value (Mesquita et al., 2018; Kaur et al., 2020).

The objective of this work was to evaluate the banana cultivars for their agronomic yield and starch characteristics.

\section{Materials and Methods}

An experiment in two crop cycles was carried out at the São Manuel Experimental Farm of the Universidade Estadual Paulista (Unesp), in the state of São Paulo, Brazil (22 $44^{\prime} 28^{\prime \prime} \mathrm{S}, 48^{\circ} 34 ' 37^{\prime \prime} \mathrm{W}$, at $740 \mathrm{~m}$ altitude). The region has a $\mathrm{Cfa}$ climate (humid subtropical climate, mesothermic), according to the Köppen-Geiger's classification system. The soil of experimental area was classified as a sandy-textured Latossolo Vermelho distroférrico, according to the Brazilian system of soil classification (Santos et al., 2013), i.e., a dystrophic Typic Hapludox (Soil Survey Staff, 1999). Average minimum, maximum, and medium temperatures, and rainfall data are as presented (Figure 1).

Crop spacing was $2.5 \mathrm{~m}$ between rows and 2.0 $\mathrm{m}$ between plants, totaling 2,000 plant $\mathrm{ha}^{-1}$, in a nonirrigated system. The experiment was carried out from January 2017 until May 2018, that is, in the first ("daughter" banana plant) and the second crop cycle ("granddaughter" banana plant).

Three bunches of each cultivar were harvested, in each replicate in the field, and the second hand was used for the isolation of starches. Bunches were harvested considering the ripening stage 1 of fruit (Von Loesecke, 1950). The following variables were evaluated: bunch weight $(\mathrm{kg})$, bunch weight of marketable fruit $(\mathrm{kg})$, fruit weight $(\mathrm{kg})$, number of hands per bunch, number of fruit per bunch, fruit length, fruit diameter, second-hand weight $(\mathrm{kg})$, and 
fruit number of the second hand. The production per plant (kg per plant) was estimated by the marketable bunch weight. The yield was calculated considering the weight of marketable bunches in a stand of 2000 plants ha-1.

Fruit were processed to isolate starches according to the methodology described by Mesquita et al. (2016). The starches were analyzed for moisture, ash, fiber, lipids, protein, total sugars, starch, amylose (Horwitz, 2005), resistant starch (Goñi et al., 1996), and phosphorus (Malavolta et al., 1997).

For the analysis of X-ray diffraction pattern and crystallinity, the starch samples were incubated in a desiccator for 10 days, with a saturated solution of $\mathrm{BaCl}_{2}$, in order to reach humidity balance. X-ray patterns were examined using a goniometer unit Rigaku MiniFlex 600 (Rotaflex, Tokyo, Japan) (Mesquita et al., 2016).

Analyses of the morphology and granule size distribution of the starches followed the methodologies described by Mesquita et al. (2016). Starches were observed in a scanning electron microscope (SEM) (Evo-LS15, Zeiss, Oberkochen, Baden-Württemberg, Germany). Starch granule sizes were analyzed in Mastersizer 2000 (Malvern Instruments Ltd., Malvern, Worcestershire, UK).

Thermal properties were analyzed using a differential scanning calorimeter DSC-Pyris 1 (Perkin Elmer, Waltham, EUA), as described by Mesquita et al. (2016). Pyris 1 software (Perkin Elmer, Norwalk, USA) was used to determine transition temperatures.

Swelling power and solubility of starches were analyzed according to the methodology of Schoch (1964).

Pasting properties were analyzed using a rapid viscoanalyzer RVA Super 4 (Newport Scientific, Warriewood, New South Wales, AU) (Mesquita et al., 2016). The starch samples $(2.5 \mathrm{~g}, 14 \% \mathrm{w} / \mathrm{w})$ were weighed, and $25 \mathrm{~g}$ of distilled water was added. The samples were equilibrated at $50^{\circ} \mathrm{C}$ for $1 \mathrm{~min}$, heated

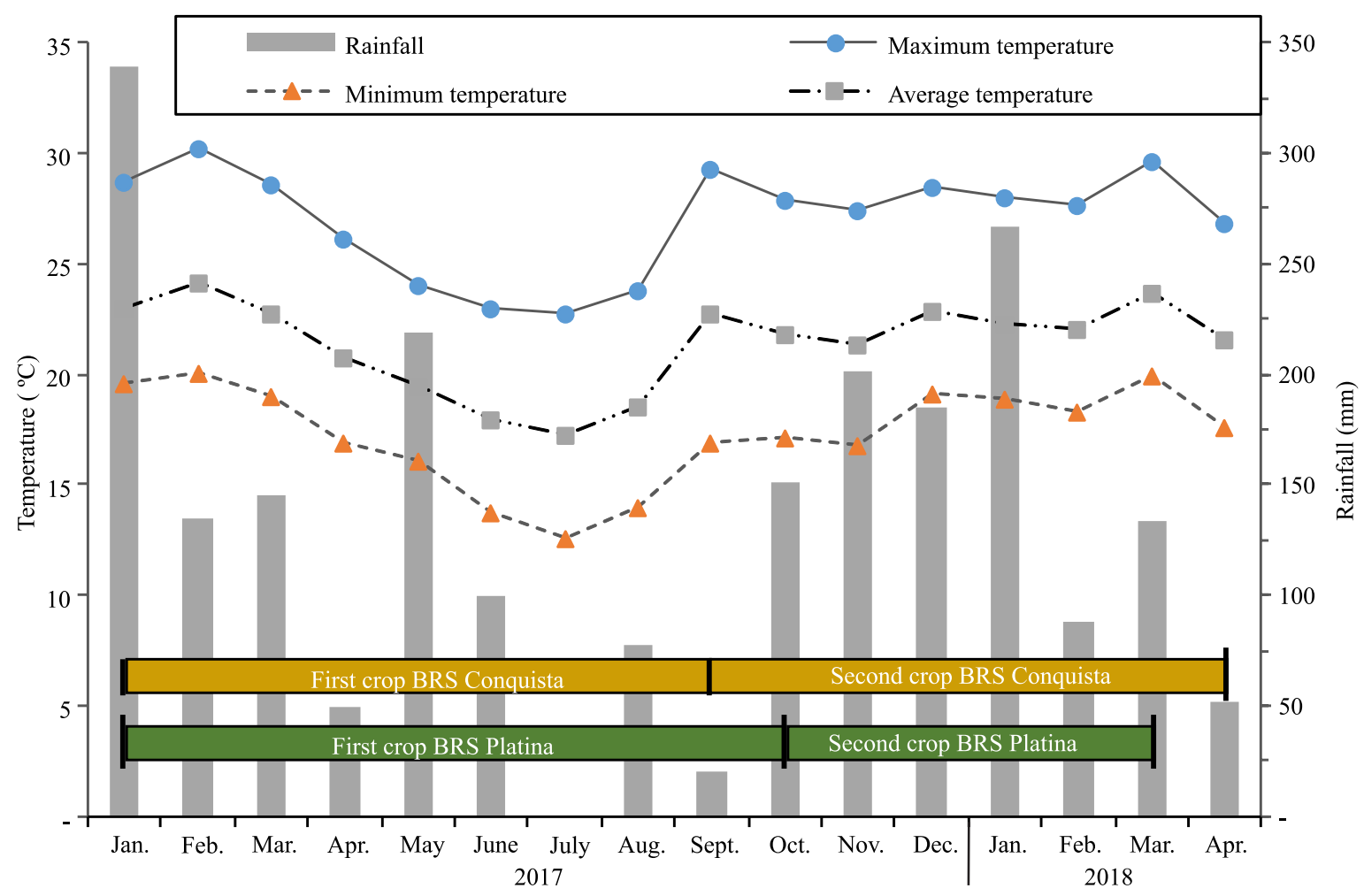

Figure 1. Minimum, maximum, average temperature, and rainfall from January 2017 until April 2018, in the experimental area. 
to $95^{\circ} \mathrm{C}$ at $6^{\circ} \mathrm{C} \mathrm{min}^{-1}$, held at $95^{\circ} \mathrm{C}$ for $5 \mathrm{~min}$ and, then, cooled to $50^{\circ} \mathrm{C}$ at $6^{\circ} \mathrm{C} \mathrm{min}-1$; stirring at $160 \mathrm{rpm}$ was applied throughout the experiment.

The experimental design was carried out in randomized complete block, in a $2 \times 2$ factorial arrangement, corresponding to two cultivars and two crop cycles of evaluation, with tree plants per experimental plot, and five replicates to analyze the plant production. The other analyses regarding the properties of starches were carried out with fruit of the second crop. The data were subjected to the test of homogeneity and normality (Shapiro-Wilk), to analyses of variance (test F) and, when significant, the means were compared by the Tukey's test, at 5\% probability. To obtain a better visualization of the evaluated variables, the principal component analysis (PCA) was performed (Rencher \& Christensen, 2012). The analysis of variance and the Tukey's test were performed using the Sisvar software. The normality test and the PCA were performed with the Minitab 17 software.

\section{Results and Discussion}

There was a significant interaction between cultivars and crop cycles for weight of marketable bunch and yield (Table 1). 'BRS Conquista' showed greater weight of marketable bunches and yield than 'BRS Platina', in both cycles, with results similar to those obtained by Pereira \& Gasparotto (2008) with plants in the first cycle, in Manaus, where the cultivar was selected. The better performance of 'BRS Conquista' shows the adaptation to cultivation regions with a subtropical climate.
'BRS Conquista' stood out for its higher bunch weight and number of fruit and hands per bunch, and for its higher number of fruit in the second bunch. However, 'BRS Platinum' showed fruit with higher weight, length and diameter, that is, despite it shows lower yield, its fruit are larger. There was higher bunch weight and number of fruit in the second bunch, in 2018 (Table 2).

Nogueira et al. (2018) found smaller number of hands (5.7), fruit per bunch (72.5), bunch weight (6.8) and productivity (12.3 $\left.\mathrm{Mg} \mathrm{ha}^{-1}\right)$ for 'BRS Platina', in cultivation in the municipality of Rio Branco, in the state of Acre, Brazil, which shows its better adaptability to the subtropical region, allowing of evaluations of commercial crops for the fresh market and industrial processing. The differences between cultivars, as well as the differences of the same cultivar in different regions are related to genetic and climatic conditions and cultural management (Nomura et al., 2013).

Table 1. Weight of marketable bunches and yield, in 2017 and 2018 crop year ${ }^{(1)}$.

\begin{tabular}{|c|c|c|c|c|}
\hline \multirow[t]{2}{*}{ Variable } & \multirow[t]{2}{*}{ Crop year } & \multicolumn{2}{|c|}{ Cultivar } & \multirow{2}{*}{$\begin{array}{c}\text { Coefficient } \\
\text { of variation } \\
(\%)\end{array}$} \\
\hline & & $\begin{array}{c}\text { BRS } \\
\text { Conquista }\end{array}$ & $\begin{array}{c}\text { BRS } \\
\text { Platina }\end{array}$ & \\
\hline \multirow{2}{*}{$\begin{array}{l}\text { Marketable } \\
\text { bunches }(\mathrm{kg})\end{array}$} & 2017 & $19.08 \mathrm{Ab}$ & $13.35 \mathrm{Ba}$ & \multirow{2}{*}{8.04} \\
\hline & 2018 & $24.46 \mathrm{Aa}$ & $14.84 \mathrm{Ba}$ & \\
\hline \multirow{2}{*}{$\begin{array}{l}\text { Yield } \\
\left(\mathrm{Mg} \mathrm{ha}^{-1}\right)\end{array}$} & 2017 & $38.15 \mathrm{Ab}$ & $26.69 \mathrm{Ba}$ & \multirow{2}{*}{8.04} \\
\hline & 2018 & $48.92 \mathrm{Aa}$ & $29.67 \mathrm{Ba}$ & \\
\hline
\end{tabular}

${ }^{(1)}$ Means followed by equal letters, uppercase in the rows and lowercase in the columns, do not differ by the Tukey's test, at $5 \%$ probability.

Table 2. Bunch weight, number of fruit and hands per bunch, average weight and fruit number of $2^{\text {nd }}$ hand, average weight, length and diameter of fruit.

\begin{tabular}{|c|c|c|c|c|c|}
\hline \multirow[t]{2}{*}{ Variable } & \multicolumn{2}{|c|}{ Cultivar } & \multicolumn{2}{|c|}{ Crop year } & \multirow{2}{*}{$\begin{array}{l}\text { Coefficient of } \\
\text { variation }(\%)\end{array}$} \\
\hline & BRS Conquista & BRS Platina & 2017 & 2018 & \\
\hline Bunch weight (kg) & $22.45 * *$ & 15.24 & $17.52 * *$ & 20.17 & 8.34 \\
\hline Number of fruit per bunch & $266.13 * *$ & 87.88 & $175.38^{\mathrm{ns}}$ & 178.63 & 4.97 \\
\hline Number of hands per bunch & $13.88 * *$ & 7.06 & $10.31^{\mathrm{ns}}$ & 10.63 & 6.18 \\
\hline Average weight of $2^{\text {nd }}$ hand $(\mathrm{kg})$ & $2.09^{\text {ns }}$ & 2.23 & $2.10^{\mathrm{ns}}$ & 2.23 & 11.07 \\
\hline Fruit number of $2^{\text {nd }}$ hand & $22.63 * *$ & 13.88 & $17.50 * *$ & 19.00 & 5.09 \\
\hline Average weight of fruit (g) & $92.75 * *$ & 161.07 & $127.49^{\text {ns }}$ & 126.33 & 11.84 \\
\hline Fruit length $(\mathrm{cm})$ & $14.46^{* *}$ & 20.02 & $16.73^{\mathrm{ns}}$ & 17.75 & 17.24 \\
\hline Fruit diameter (mm) & $34.16^{* *}$ & 39.55 & $36.66^{\mathrm{ns}}$ & 37.05 & 4.79 \\
\hline
\end{tabular}

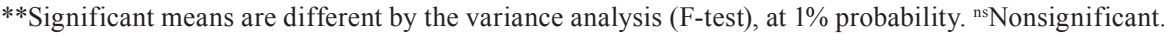


Data showed that both BRS Conquista and BRS Platina cultivars are promising for varietal diversification in subtropics, as they had higher yields than those obtained by Bolfarini et al. (2014), who observed $13.5 \mathrm{Mg}^{\text {ha-1 }}$ average yield in 'Prata-anã' (AAB - Prata subgroup), in the same region. This also shows that 'BRS Platina' is a good alternative among bananas of the Prata subgroup.

Analysis of the chemical composition of the isolated starches showed that 'BRS Conquista' starch had $11.52 \%$ moisture, $87.20 \%$ starch, $0.04 \%$ total sugars, $0.39 \%$ protein, $0.16 \%$ fiber, $0.3 \%$ lipids, and $0.4 \%$ ash. Starch of 'BRS Conquista' showed higher contents of protein and fiber than that of 'BRS Platina'. 'BRS Platina' starch had $10.35 \%$ moisture, $88.46 \%$ starch, $0.09 \%$ total sugar, $0.20 \%$ protein, $0.10 \%$ fiber, $0.35 \%$ lipid, and $0.4 \%$ ash. These data show efficiency in the starch isolation process, as the number of minor constituents in the starch composition depends on the plant and the methods of extraction and purification. Low contents of these substances indicate best commercial quality of starch (Peroni et al., 2006).

Scanning electronic microscopy analysis showed that starch granules of 'BRS Conquista' are elongated and oval, flat, and with some irregularities on their surface (Figure $2 \mathrm{~A}$ ), which was also observed for banana starches of the AAB genome (Wang et al., 2019).

Although 'BRS Conquista' is classified in a specific subgroup (AAB - Conquista Subgroup), its fruit are similar to those of the 'Silk' banana (AAB - Silk subgroup). Starch of 'BRS Platina' shows elongated and flat forms, with a smooth surface (Figure 2 B) that is similar to the starch morphology of FHIA-18 (genome AAAB - Prata/Pome type) (Mesquita et al., 2016). The shape and size of starch granules are among the most important characteristics to determine the functionality of starch. Knowledge on the variation the size of starch granules can be useful for analyzing the qualities of food and processing (Niu et al., 2019).

The particle size distribution showed that the starch granule sizes varied from 6 to $60 \mu \mathrm{m}$. 'BRS Platina' displayed a higher proportion of starch granules between 11 and $15 \mu \mathrm{m}-$, while 'BRS Conquista' exhibited a similar proportion of starch granules between 11 and $15 \mu \mathrm{m}$ and 21 and $30 \mu \mathrm{m}$ (Figures 2 $\mathrm{C}$, Table 3). The average size of banana starch granules is quite variable (16 to $45 \mu \mathrm{m}$ ) (Utrilla-Coello et al.,
2014), but the granule sizes of the studied starches were close to that of banana starches of the same genomic groups (Mesquita et al., 2016). The higher proportion of small granules of 'BRS Platina' can affect the physicochemical properties and the use of starch (Mesquita et al., 2016).

Starches isolated of two cultivars showed a B-type diffraction pattern, with the most intense peaks occurring at $5,15,17,22$, and $24^{\circ} 2 \theta$ (Figure 2 D). X-ray diffraction models (A, B, or C) are classified based on variations of the water content and the double helix packing configuration of amylopectin (Denardin \& Silva, 2009). Type B starches have greater resistance to enzymatic and acid hydrolysis, with greater sensitivity to hydrothermal treatment, which are important factors for applications in processed foods (Huang et al., 2015; Mesquita et al., 2016). However, other studies report that starches isolated from different banana cultivars show variations in their diffraction patterns, and this characteristic interferes with the rheological properties of starch (Utrilla-Coello et al., 2014; Mesquita et al., 2016; Marta et al., 2019).

'BRS Conquista' showed higher relative crystallinity (Table 3), with a value within the range mentioned by Marta et al. (2019) for banana starches of the AAB genotypes (33.2 to $39.4 \%$ ). The lower crystallinity of 'BRS Platina' starch can be related to its higher proportion of small granules. Smaller granules have lower crystallinity, which may be related to the fact that molecules closer to the hilum are more constrained by space to align into crystallites than those closer to the surface (Dhital et al., 2011). Changes in the crystallinity of starches from the same source can interfere with the characteristics of viscosity, gelation and matrix formation, as well as in the rearrangement of starch during processing or storage, thus affecting the texture, stability, quality, and digestibility of food products (Fernandes et al., 2019).

The amylose values found in the studied cultivars were similar to those found by Mesquita et al. (2016) and Wang et al. (2019), the higher content was measured in 'BRS Platina' (Table 3). Amylose percentage affects some properties that are particularly useful in the food industry, such as gelatinization, solubility, pasting characteristics, and texture (Denardin \& Silva, 2009). Additionally, starches with high amylose contents can form excellent films that are interesting from an industrial point of view (Mesquita et al., 2016). 
Starches did not differ for phosphorus (Table 3), but the values found were higher than those observed by Mesquita et al. (2016) for starches of banana 'Nanicão' and 'Grand Naine' grown in the same region $(0.003 \%)$. Starch-bound phosphorus affects the colloidal capacity, interfering with properties such as swelling power,
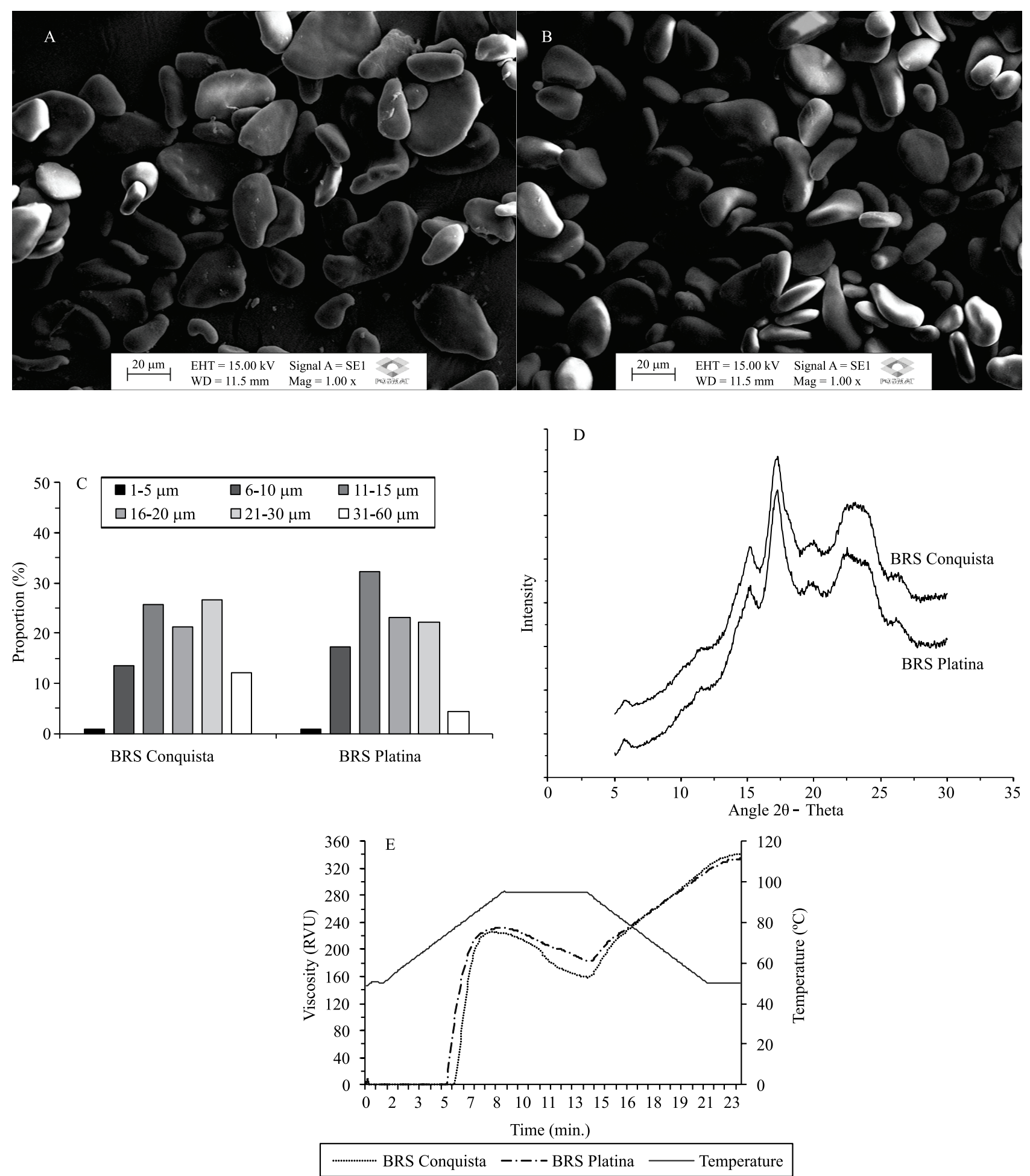

Figure 2. Morphology of starch granules (A-B), distribution of the granule size (C), X-ray diffraction patterns (D), and RVA viscoamylogram (E) of banana starches. 
paste clarity, starch gel viscosity, and retrogradation (Mesquita et al., 2018).

Banana starches had high content of resistant starch (RS), with higher percentage observed in 'BRS Platina' starch (Table 3). The differences observed for resistant starch contents between cultivars may be associated with crystallinity, granule size, and amylose content (Zhang \& Hamaker, 2012). In their study on banana, Bi et al. (2017) observed impacts of these factors on the extent of digestibility of banana starches, which shows that the selection of genotypes can be an important parameter. The higher content of resistant starch of 'BRS Platina' may add value to this cultivar, as the resistant starch improves the functional properties of several foods (Mesquita et al., 2018).

The swelling power (SP) and solubility (SS) provide evidence of the magnitude of interaction between starch chains within both the amorphous and crystalline domains. There were differences for SP among banana starches, which can be attributed to disparities in bonding forces within the starch granule. 'BRS Conquista' showed lower SP and SS, which may reflect a more ordered, more strongly bonded, denser granule structure (Copeland et al., 2009) (Table 3).

The starch of 'BRS Conquista' had higher gelatinization temperatures and enthalpy range than 'BRS Platina', which can be related to the higher crystallinity of this starch (Table 3). According to Jane et al. (1999) lower gelatinization temperatures such as those observed for 'BRS Platina' starch may be related to the size of the starch granule and, even more, to the distribution of amylose and amylopectin within the granule. These authors also reported that starches with greater amylopectin chain length have higher gelatinization temperatures, which may be a structural characteristic of 'BRS Conquista' starch.

In the thermal analysis of the retrograded starches, 'BRS Platina' showed higher values of retrogradation temperature and enthalpy range; however, for both banana starches, the dissociation temperatures of retrogradation was observed as lower than the gelatinization temperatures because small and/ or imperfect crystals were formed during the retrogradation (Jane et al., 1999). The retrogradation

Table 3. Physicochemical characteristics of banana starches.

\begin{tabular}{|c|c|c|c|}
\hline Characteristics & BRS Conquista & BRS Platina & $\mathrm{CV}(\%)$ \\
\hline Granule size $(\mu \mathrm{m})$ & $34.74 * *$ & 29.84 & 0.43 \\
\hline Crystallinity (\%) & $33.64 * *$ & 29.78 & 0.32 \\
\hline Amylose (\%) & 28.82 & $32.59 * *$ & 0.32 \\
\hline Phosphorus (\%) & $0.0058^{\text {ns }}$ & 0.0060 & 0.00 \\
\hline Resistant starch (\%) & 69.84 & $74.55^{* *}$ & 1.7 \\
\hline Swelling power $\left(\mathrm{g} \mathrm{g}^{-1}\right)$ & 26.77 & $30.21 * *$ & 0.30 \\
\hline Solubility (\%) & 19.21 & $21.97 * *$ & 2.79 \\
\hline \multicolumn{4}{|l|}{ Thermal properties } \\
\hline $\mathrm{T}_{\text {ogel }}\left({ }^{\circ} \mathrm{C}\right), \mathrm{T}_{\mathrm{oR}}\left({ }^{\circ} \mathrm{C}\right)$ & $71.19 * *, 45.01$ & $69.78,47.91 * *$ & $0.26,0.82$ \\
\hline $\mathrm{T}_{\mathrm{p} \text { gel }}\left({ }^{\circ} \mathrm{C}\right), \mathrm{T}_{\mathrm{pR}}\left({ }^{\circ} \mathrm{C}\right)$ & $74.33 * *, 52.52$ & $72.38,55.35^{* *}$ & $0.24,0.31$ \\
\hline $\mathrm{T}_{\mathrm{c} \text { gel }}\left({ }^{\circ} \mathrm{C}\right), \mathrm{T}_{\mathrm{c} \mathrm{R}}\left({ }^{\circ} \mathrm{C}\right)$ & $80.05^{* *}, 61.12$ & $75.01,66.64 * *$ & $0.25,0.39$ \\
\hline$\Delta \mathrm{T}_{\text {gel }}\left({ }^{\circ} \mathrm{C}\right), \Delta \mathrm{T}_{\mathrm{R}}\left({ }^{\circ} \mathrm{C}\right)$ & $8.85^{* *}, 16.11$ & $5.23,18.73 * *$ & $2.81,3.57$ \\
\hline$\Delta \mathrm{H}_{\text {gel }}\left(\mathrm{J} \mathrm{g}^{-1}\right)$ & $16.27^{* *}, 1.79$ & $8.05,7.20 * *$ & $5.06,3.25$ \\
\hline $\mathrm{R}(\%)$ & 22.19 & $44.25 * *$ & 0.40 \\
\hline \multicolumn{4}{|l|}{ Pasting properties (RVU) } \\
\hline Viscosity peak (RVU) & 226.02 & $232.58 * *$ & 0.04 \\
\hline Breakdown (RVU) & $67.06^{* *}$ & 50.37 & 1.37 \\
\hline Final viscosity (RVU) & $341.39 * *$ & 334.52 & 0.32 \\
\hline Setback (RVU) & $182.42 * *$ & 152.30 & 0.15 \\
\hline Pasting temperature $\left({ }^{\circ} \mathrm{C}\right)$ & $76.98^{* *}$ & 74.03 & 0.13 \\
\hline
\end{tabular}

**Significant difference by the F-test, at $1 \%$ probability. ${ }^{\mathrm{n}}$ Nonsignificant. $\mathrm{CV}$, coefficient of variation. $\mathrm{T}_{\mathrm{o}}$, onset temperature; $\mathrm{T}_{\mathrm{p}}$, peak temperature; $\mathrm{T}_{\mathrm{c}}$, conclusion temperature; $\Delta \mathrm{H}$, enthalpy change; $\mathrm{R}$, retrogradation rate. 
rate reported for cereal starch of banana starches was close to 30-50\% range (Jane et al., 1999).

Results for the pasting temperatures were in agreement with the data of the thermal gelatinization analysis, by which starch of 'BRS Conquista' showed higher temperatures, indicating that the swelling of the starch granules is delayed during the heating of the starch dispersion (Figure 2 E, Table 3). This may be due to the distribution of the length of the amylopectin branch chain and the molecular size of amylose (Jane et al., 1999).

The studied starches showed lower viscosity, degradation, final viscosity, and retrogradation than banana starches isolated from other cultivars grown in the same region (Mesquita et al., 2016), which makes these cultivars very interesting for diversification and industrialization.

The increased consistency of 'BRS Platina' starch in the heating and cooling process, measured with continuous shear force, makes it potentially useful in products that require sterilization (Figure $2 \mathrm{E}$, Table 3). The pasting properties of 'BRS Conquista' starch showed stability in the cooking process, but its viscosity was higher when cooled, indicating that it is less stable in the cooling process (Figure 2 E, Table 3 ). These are vital aspects to consider when incorporating these starches into food production processes.

Only the first two components (PC1 and PC2) explained $88.9 \%$ of total variability of production variables and starch properties (Figure 3). PC1 explained $82.5 \%$ of the data and showed the cultivars separation, which were positioned on opposite sides in PC1 (Figure $3 \mathrm{~A}$ ). According to PC1 loadings, except for the weight of the second hand $(\mathrm{AWH})$, all other variables contributed to this separation (Figure $3 \mathrm{~B}$ ). The PC1 loadings also allow to verify that the yield and fruit size (FD, fruit diameter; FL, fruit length; and $\mathrm{FW}$, fruit weight) are on opposite sides, that is, the increase of one parameter occurs in detriment of the other one. The higher yield observed for 'BRS Conquista' is correlated to starch with higher granule size (D 4.3), crystallinity (IC), breakdown (BD), setback (SB) and range of gelatinization temperature $(\triangle \mathrm{T}$ gel). Larger fruit of 'BRS Platina' are correlated with higher levels of phosphorus (P), resistant starch (RS), amylose (AMY), swelling power (SP), and solubility (SS) (Figure 3 B). The PC2 explained 6.5\% of the variability that was evidenced mainly by the weight of second hand.

The observed differences for agronomic parameters and starch properties indicate that these genotypes could be targeted for use in different food industries. 'BRS Platina' starch had higher swelling power and lower breakdown, which are desirable characteristics for use as a thickener in foods that require a long time of heat treatment under agitation. Due to its lower tendency to retrograde, this starch can be also interesting as a gelling and thickening agent in refrigerated and frozen foods (Takeiti et al., 2020). Starch from 'BRS Conquista' showed less resistant starch that may be useful in hydrolysis processes. This starch also had lower swelling power and solubility, which is desirable for certain industrial applications, as it offers good crispness, and low water and fat retention.
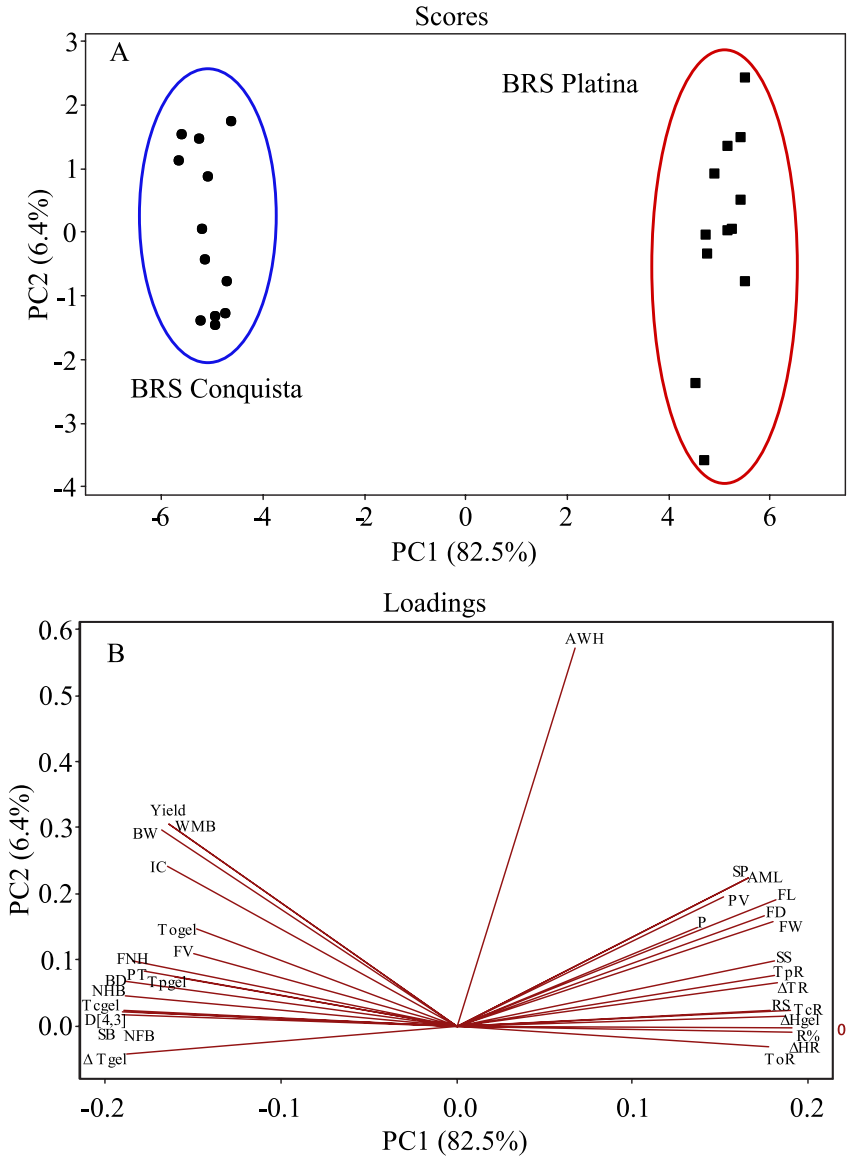

Figure 3. Principal component analysis of production variables and starch properties of banana genotypes. A, observation scores; B, loadings of variables on PC1 and PC2. 


\section{Conclusions}

1. Because of their yield performance, both 'BRS Conquista' and 'BRS Platina' bananas show potential for cultivation in subtropical conditions.

2. The physicochemical properties of starches isolated from green fruit of 'BRS Conquista' and 'BRS Platina' have different characteristics.

3. The sets of starch characteristics of 'BRS Conquista' and 'BRS Platina' show potential for exploitation as industrial ingredients.

4. 'BRS Platina' starch is an option for increasing functional properties in processed foods due to its high resistant starch content and low retrogradation tendency.

5. 'BRS Conquista' starch stands out for its potential use in hydrolysis processes.

\section{Acknowledgments}

To Conselho Nacional de Desenvolvimento Científico e Tecnológico (CNPq), under grant numbers 304455/2017-2 and 302827/2017-0.

\section{References}

BI, Y.; ZHANG, Y.; JIANG, H.; HONG, Y.; GU, Z.; CHENG L.; LI, Z.; LI, C. Molecular structure and digestibility of banana flour and starch. Food Hydrocolloids, v.72, p.219-227, 2017. DOI: https:/doi.org/10.1016/j.foodhyd.2017.06.003.

BOLFARINI, A.C.B.; JAVARA, F.S.; LEONEL, S.; LEONEL, M. Crescimento, ciclo fenológico e produção de cinco cultivares de bananeira em condições subtropicais. Revista Raízes e Amidos Tropicais, v.10, p.74-89, 2014.

CASTRICINI, A.; COELHO, E.F.; RODRIGUES, M.G.V.; COUTINHO, R.C. Caracterização pós-colheita de frutos de bananeira 'BRS Platina' de primeiro ciclo, sob regulação do déficit de irrigação. Revista Brasileria de Fruticultura, v.34, p.1013-1021, 2012. DOI: https://doi.org/10.1590/S010029452012000400007.

COPELAND, L.; BLAZEK, J.; SALMAN, H.; TANG, M.C. Form and functionality of starch. Food Hydrocolloids, v.23, p.15271534, 2009. DOI: https://doi.org/10.1016/j.foodhyd.2008.09.016.

DENARDIN, C.C.; SILVA, L.P. da. Estrutura dos grânulos de amido e sua relação com propriedades físico-químicas. Ciência Rural, v.39, p.945-954, 2009. DOI: https://doi.org/10.1590/S010384782009005000003 .

DHITAL, S.; SHRESTHA, A.K.; FLANAGAN, B.M.; HASJIM, J.; GIDLEY, M.J. Cryo-milling of starch granules leads to differential effects on molecular size and conformation. Carbohydrate Polymers, v.84, p.1133-1140, 2011. DOI: https://doi.org/10.1016/j.carbpol.2011.01.002.
FERNANDES, D. de S.; SANTOS, T.P.R. dos; FERNANDES, A.M.; LEONEL, M. Harvest time optimization leads to the production of native cassava starches with different properties. International Journal of Biological Macromolecules, v.132, p.710-721, 2019. DOI: https://doi.org/10.1016/j. ijbiomac.2019.03.245.

GOÑI, I.; GARCÍA-DIZ, L.; MAÑAS, E.; SAURA-CALIXTO, F. Analysis of resistant starch: a method for foods and food products. Food Chemistry, v.56, p.445-449, 1996. DOI: https://doi.org/10.1016/0308-8146(95)00222-7.

HORWITZ, W. (Ed.). Official Methods of Analysis of AOAC International. $18^{\text {th }}$ ed. Gaithersburg: AOAC International, 2005. Official Methods 920.152, 920.86, 923.03, 923.05, 934.06, 968.28, 996.11.

HUANG, J.; ZHAO, L.; MAN, J.; WANG, J.; ZHOU, W.; HUAI, H.; WE, C. Comparison of physicochemical properties of B-type nontraditional starches from different sources. International Journal of Biological Macromolecules, v.78, p.165-172, 2015. DOI: https://doi.org/10.1016/j.ijbiomac.2015.04.006.

JANE, J.; CHEN, Y.Y.; LEE, L.F.; MCPHERSON, A.E.; WONG, K.S.; RADOSAVLJEVIC, M.; KASEMSUWAN, T. Effects of amylopectin branch chain length and amylose content on the gelatinization and pasting properties of starch. Cereal Chemistry, v.76, p.629-637, 1999. DOI: https://doi.org/10.1094/ CCHEM.1999.76.5.629.

KAUR, L.; DHULL, S.B.; KUMAR, P.; SINGH, A. Banana starch: properties, description, and modified variations - a review. International Journal of Biological Macromolecules, v.165, p.2096-2102, 2020. DOI: https://doi.org/10.1016/j. ijbiomac.2020.10.058

MALAVOLTA, E.; VITTI, G.C.; OLIVEIRA, S.A. Avaliação do estado nutricional das plantas: princípios e aplicações. 2.ed. Piracicaba: Potafos, 1997. 319p.

MARTA, H.; CAHYANA, Y.; DJALI, M.; ARCOT, J.; TENSISKA, T. A comparative study on the physicochemical and pasting properties of starch and flour from different banana (Musa spp.) cultivars grown in Indonesia. International Journal of Food Properties, v.22, p.1562-1575, 2019. DOI: https://doi.org/10.1080/10942912.2019.1657447.

MESQUITA, C. de B.; GARCIA, E.L.; BOLFARINI, A.C.B.; LEONEL, S.; FRANCO, C.M.L.; LEONEL, M. Phosphate fertilization changes the characteristics of 'Maçã' banana starch. International Journal of Biological Macromolecules, v.112, p.1138-1145, 2018. DOI: https://doi.org/10.1016/j. ijbiomac.2018.02.065

MESQUITA, C. de B.; LEONEL, M.; FRANCO, C.M.L.; LEONEL, S.; GARCIA, E.L.; SANTOS, T.P.R. dos. Characterization of banana starches obtained from cultivars grown in Brazil. International Journal of Biological Macromolecules, v.89, p.632-639, 2016. DOI: https://doi.org/10.1016/j.ijbiomac.2016.05.040.

NIU, S.; LI, X-Q.; TANG, R.; ZHANG, G.; LI, X.; CUI, B.; MIKITZEL, L.; HAROON, M. Starch granule sizes and degradation in sweet potatoes during storage. Postharvest 
Biology and Technolology, v.150, p.137-147, 2019. DOI: https://doi.org/10.1016/j.postharvbio.2019.01.004.

NOGUEIRA, S.R.; ANDRADE NETO, R. de C.; CAPISTRANO, M. da C.; LESSA, L.S.; ALÉCIO, M.R.; SANTOS, V.B. dos. Performance of banana genotypes in Rio Branco, Acre, Brazil. Revista Brasileira de Ciências Agrárias, v.13, e5576, 2018. DOI: https://doi.org/10.5039/agraria.v13i4a5576.

NOMURA, E.S.; MORAES, W.S.; DAMATTO JUNIOR, E.R.; FUZITANI, E.J.; SAES, L.A.; AMORIM, E.P.; SILVA, S.O. Evaluation of banana genotypes over two crop cycles under subtropical conditions in the Ribeira Valley, São Paulo, Brazil. Acta Horticulturae, v.986, p.61-70, 2013. DOI: https://doi.org/10.17660/ActaHortic.2013.986.4.

PEREIRA, J.C.R.; GASPAROTTO, L. BRS Conquista: nova cultivar de bananeira para o agronegócio da banana no Brasil. Manaus: Embrapa Amazônia Ocidental, 2008. (Embrapa Amazônia Ocidental. Comunicado técnico, 60). Available at: $<$ https:/ainfo.cnptia.embrapa.br/digital/bitstream/CPAA-200909/21021/1/Com Tec 60.pdf>. Accessed on: July 272021.

PERONI, F.H.G.; ROCHA, T.S.; FRANCO, C.M.L. Some structural and physicochemical characteristics of tuber and root starches. Food Science and Technology International, v.12, p.505-513, 2006. DOI: https://doi.org/10.1177/1082013206073045.

RENCHER, A.C.; CHRISTENSEN, W.F. Methods of multivariate analysis. $3^{\text {th }}$ ed. New York: J. Wiley, 2012. 758p. DOI: https://doi.org/10.1002/9781118391686.

SANTOS, H.G. dos; JACOMINE, P.K.T.; ANJOS, L.H.C. dos; OLIVEIRA, V.A. de; LUMBRERAS, J.F.; COELHO, M.R.; ALMEIDA, J.A. de; CUNHA, T.J.F.; OLIVEIRA, J.B. de. Sistema brasileiro de classificação de solos. 3.ed. rev. e ampl. Brasília: Embrapa, 2013. 353p.

SCHOCH, J.T. Swelling power and solubility of granular starches. In: WHISTLER, L.R.; SMITH, J.R.; BEMILLER, N.J. (Ed.). Methods in carbohydrate chemistry. London: Academic Press, 1964. p.106-113.
SOIL SURVEY STAFF. Soil taxonomy: a basic system of soil classification for making and interpreting soil surveys. $2^{\text {nd }}$ ed. Washington: USDA, NRCS, 1999. Available at: <https://www. nrcs.usda.gov/Internet/FSE_DOCUMENTS/nrcs142p2_051232. pdf $>$. Accessed on: July 272021.

TAGLIAPIETRA, B.L.; FELISBERTO, M.H.F.; SANCHES, E.A.; CAMPELO, P.H.; CLERICI, M.T.P.S. Non-conventional starch sources. Current Opinion in Food Science, v.39, p.93-102, 2021. DOI: https://doi.org/10.1016/j.cofs.2020.11.011.

TAKEITI, C.Y.; REIS, R.C.; CARVALHO, C.W.P. de; VIANA, E. de S.; OLIVEIRA, N.A. de; JESUS NETA, P. de; OLIVEIRA, L.A. de. Propriedades tecnológicas de amidos isolados de plátanos e bananas da coleção de germoplasma da Embrapa. Rio de Janeiro: Embrapa Agroindústria de Alimentos, 2020. 26p. (Embrapa Agroindústria de Alimentos. Boletim de Pesquisa e Desenvolvimento, 36).

UTRILLA-COELLO， R.G.; RODRÍGUEZ-HUEZO, M.E.; CARRILLO-NAVAS, H.; HERNÁNDEZ-JAIMES, C.; VERNON-CARTER, E.J.; ALVAREZ RAMIREZ, J. In vitro digestibility, physicochemical, thermal and rheological properties of banana starches. Carbohydrate Polymers, v.101, p.154-162, 2014. DOI: https://doi.org/10.1016/j.carbpol.2013.09.019.

VON LOESECKE, H.W. Bananas. $2^{\text {nd }}$ rev. ed. New York: Interscience, 1950.

WANG, J.-S.; WANG, A.-B.; MA, W.-H.; XU, B.-X.; ZANG, X-P..; TAN, L.; JIN, Z.-Q.; LI, J.-Y. Comparison of physicochemical properties and in vitro digestibility of starches from seven banana cultivars in China. International Journal of Biological Macromolecules, v.121, p.279-284, 2019. DOI: https://doi.org/10.1016/j.ijbiomac.2018.09.140.

ZHANG, P.; HAMAKER, B.R. Banana starch structure and digestibility. Carbohydrate Polymers, v.87, p.1552-1558, 2012. DOI: https://doi.org/10.1016/j.carbpol.2011.09.053.

ZHU, F. Underutilized and unconventional starches: why should we care? Trends in Food Science and Technology, v.100, p.363373, 2020. DOI: https://doi.org/10.1016/j.tifs.2020.04.018. 